\title{
REMOTE ISLAND TOURISM: A CASE STUDY IN FIJI
}

\author{
HIROSHI KATO \\ Centre for Advanced Tourism Studies, Hokkaido University, Japan
}

\begin{abstract}
The purpose of this paper is to make clear that "Remote island tourism" is one of the frontiers for South Pacific nations. Fiji plays a vital role in this paper as the main case study for pushing forward the idea. In order to confirm the existing situation and to evaluate the potential of remote island tourism, the author conducted field surveys to remote islands, including the Lau archipelago, Lomaiviti archipelago, and Kadavu island in Fiji. They sit on the eastern side or southern side of the Fiji main island, Viti Levu. It was confirmed that signs of long periods of cultural interchanges between different races clearly remain on remote islands in forms such as architectural styles. Based on the observations obtained from the field surveys, this study concludes that "Remote island tourism" is one of the frontiers for South Pacific nations. This study identified that the lifestyle of the remote islanders can be one of the tourist resources for people who live in urbanised areas. Regarding ways to deal with associated challenges, this paper suggests that "Remote island tourism" should be pursued in step with developments of social basic needs including transportation in the remote islands.
\end{abstract}

Keywords: remote, Viti Levu., Lau, Kadavu, Bau, Levuka, Lakeba, roof, resource, jetty.

\section{INTRODUCTION}

Fiji has been reputed to be a leading resort destination in the South Pacific. Foreign inbound tourists numbered 755,000 in 2016 [1]. "Blue sea and white beach" have long been placed at the centre of the destination images of Fiji, and tourism development has been promoted on a full scale since around end of the 20th century. Neighbouring nations, however, have been pursuing similar destination images. In addition, Fiji's tourist destinations are unevenly distributed on the western coast of Viti Levu. Therefore, it is reasonable for Fiji to make efforts to establish a stratified destination image and to expand tourist destinations nationwide. Little specific information, however, has been gained on what kinds of local resources exist and how they can be used for tourism promotion beside the western coast of Viti Levu.

It is generally believed that several thousand years ago Papuans firstly migrated to Fiji and that they were followed by Melanesians and then Polynesians [2]. Times advanced to the modern and in the early 1800s, sandalwood trade brought Europeans to Levuka because this fragrant wood was discovered north of Ovalau Island [3]. With this kind of historical background, it is easy to understand that Fijian culture has been influenced by those of several races and folks.

The 320 islands which comprise Fiji are spread over an area of 709,700 sq. km [4]. The total population of Fiji is estimated at about 850,000, and national capital Suva lies on Viti Levu, the largest island in the nation. Together with the second largest island called Vanua Levu, more than $90 \%$ of the national total population live on the two islands.

The purpose of this paper is to make clear that "Remote island tourism" is one of the frontiers for South Pacific nations. "Remote islands" in this paper exclude largest-class islands or socioeconomically most advanced island in a nation such as the capital island. In the case of Fiji, Viti Levu and Vanua Levu are not object islands of this paper.

This study concludes that "Remote island tourism" is one of the frontiers for South Pacific nations, it also identified that lifestyle of the remote islanders can be one of the tourist resources for people who live in urbanised areas. Regarding ways to deal with associated 
challenges, this paper suggests that "Remote island tourism" should be pursued in step with developments of social basic needs including transportation in the remote islands.

\section{FIELD VISITS FOR REMOTE ISLAND TOURISM}

\subsection{General}

In this paper, Case Study Method is adopted taking into consideration of both research accuracy and efficiency. As discussed in the previous section, there are more than 300 islands in Fiji, which are spread over about 700,000 sq. km (Fig. 1). Distances between ports and islands are shown in Table 1.

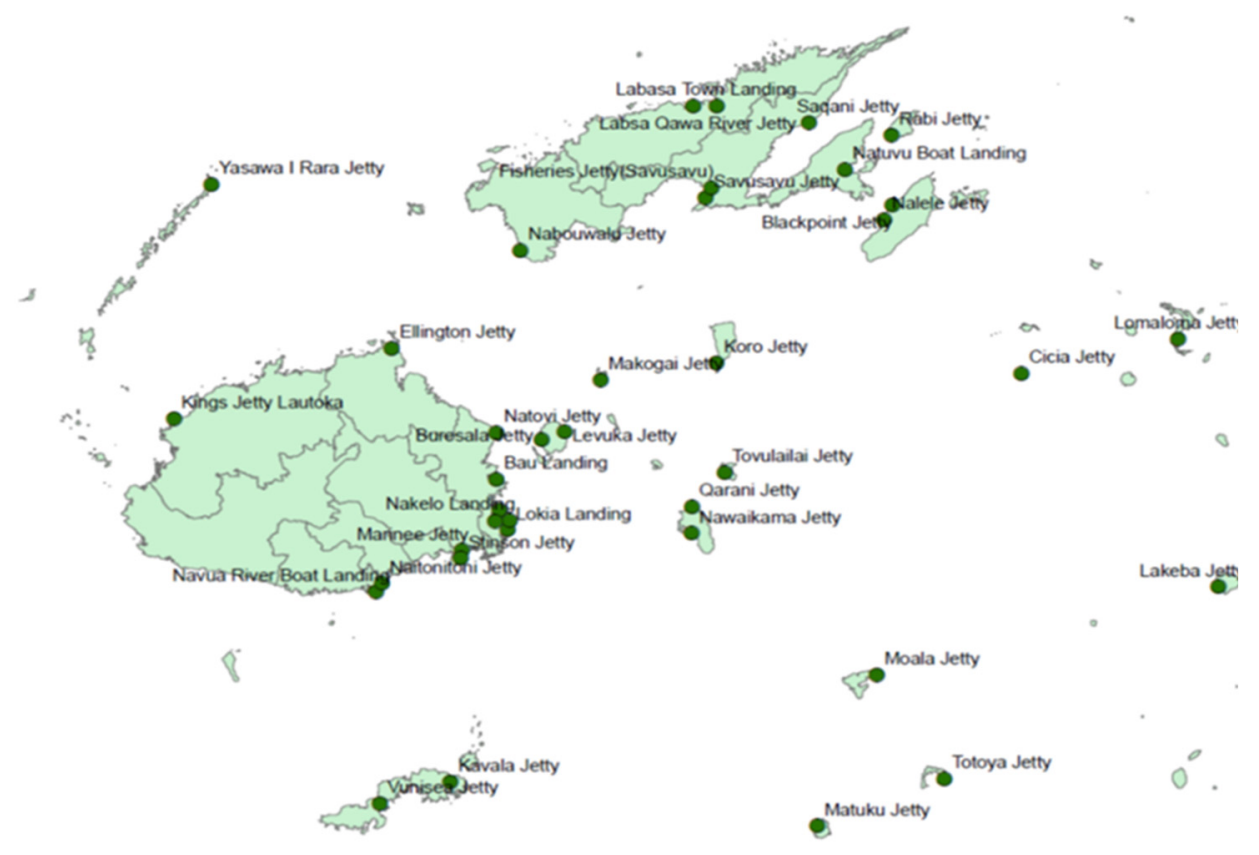

Figure 1: Fiji Islands. (Source: Kato [5].)

Table 1: Distances between ports. (Source: Hydrographic office, Fiji Navy [6].)

\begin{tabular}{|c|c|c|c|c|c|c|c|c|c|}
\hline PORT & SUVA & TOTOYA & MATUKU & MOALA & LAKEBA & CICIA & V.BALAV LEVUKA & VUNISEA \\
\hline SUVA & & 113 & 99 & 95 & 167 & 138 & 165 & 52 & 59 \\
\hline TOTOYA & & & 27 & 29 & 76 & 83 & 116 & 106 & 118 \\
\hline MATUKU & & & & 46 & 103 & 104 & 141 & 102 & 97 \\
\hline MOALA & & & & & 74 & 64 & 101 & 87 & 115 \\
\hline LAKEBA & & & & & & 45 & 55 & 143 & 187 \\
\hline CICIA & & & & & & & 39 & 103 & 165 \\
\hline V.BALAVU & & & & & & & 125 & 205 \\
\hline LEVUKA & & & & & & & & & 94 \\
\hline
\end{tabular}

Unit: nautical miles. 
Object islands for the case study are carefully evaluated and selected. Because existing tourist destinations are unevenly distributed on the western coast of Viti Levu. Therefore, it is appropriate to focus on rather eastward or southward from the viewpoint of information gathering. Object islands for the case study are selected taking into consideration of sizes (land area and population) and geographical distribution: Lau archipelago, Lomaiviti archipelago, and Kadavu Island.

\subsection{Lau archipelago}

Lau archipelago lies between Melanesian Fiji and Polynesian Tonga, and is composed of about sixty islands and islets, about thirty are inhabited. This archipelago has a population of about 10,000 in total [7]. In July 2016 Arthur visited six islands among the Lau archipelago aboard MV Iloilovatu, which Fiji Government owned and operated for disaster relief or transportation of the government supplies for island people (560 GRT, $56 \mathrm{~m}$ in length, 17 crew members). Itinerary of field visits by the MV Iloilovatu including land area and population of the visited island is shown on Table 2. Arthur spent all nights aboard the ship during this field visits. MV Iloilovatu had been used as a training vessel of a Japanese high school for fishery education.

Table 2: Itinerary of field visits by Iloilovatu.

\begin{tabular}{lcl}
\hline \multicolumn{2}{l}{ July 2016} & \multicolumn{1}{c}{ ACTIVITIES } \\
\hline 10 & $\mathrm{~S}$ & Departure from Suva Port \\
11 & $\mathrm{M}$ & Moala Is. (65 sq.km and 1,384 population) \\
12 & $\mathrm{~T}$ & Totoya Is. (28 sq.km and 538 population) \\
13 & $\mathrm{~W}$ & Totoya Is. \\
14 & $\mathrm{R}$ & Matuku Is. (57 sq.km and 672 population) \\
15 & $\mathrm{~F}$ & Matuku Is. \\
16 & $\mathrm{Sa}$ & Lakeba Is. (59.5 sq.km and 1,751 population) \\
17 & $\mathrm{~S}$ & Lakeba Is. \\
18 & $\mathrm{M}$ & Lakeba Is. \\
19 & $\mathrm{~T}$ & Vanua Balavu Is. (57 sq.km and 1,799 population) \\
20 & $\mathrm{~W}$ & Vanua Balavu Is. \\
21 & $\mathrm{R}$ & Arrive at Cicia Is. (34 sq.km and 1,024 population) \\
22 & $\mathrm{~F}$ & Arrive at Cicia Is. \\
23 & $\mathrm{Sa}$ & Arrival at Suva Port \\
\hline
\end{tabular}

2.2.1 Lakeba island

Lakeba island was an important meeting place between Fijians and Tongans throughout their early history. Tonga is geographically nearer than Viti Levu from the Southern Lau islands. In addition, the trade wind blows from the east to the west. Tongan influence has left its remarkable marks on the Lau soil [4].

Not only religious people but also warriors came to the Lakeba island together with Tongan culture. The first Christian missionaries to Fiji landed at Lakeba in 1830 and Ma'af, Tongan chief established himself at Lomaloma, Northern Lau island [4]. Tongan influence can still be found in various fields including architectural style. In Fiji architectural styles of most houses are characterised in square-shaped ends. Architectural styles of Lauan houses 
are, however, tend to be rounded, following the Tongan practice (Fig. 2). This Tongan architectural style with a rounded roof can be seen not only for public buildings (Fig. 3) but also for private houses.

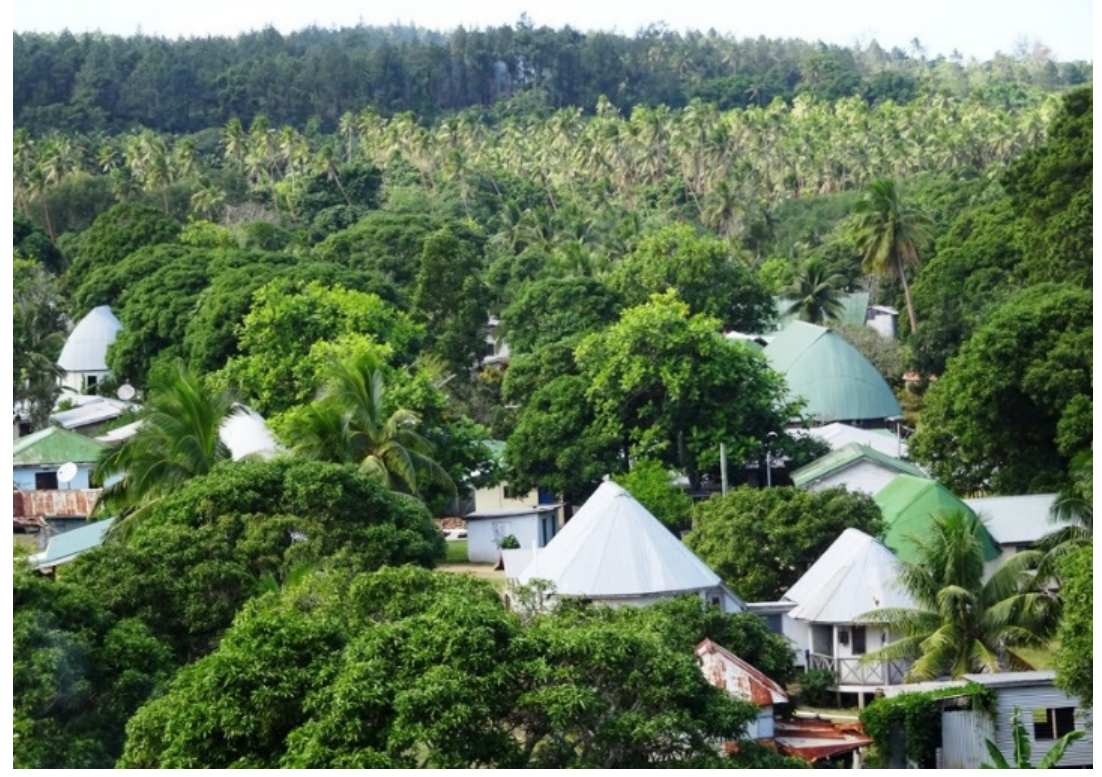

Figure 2: General view of Tubou village, Lakeba island.

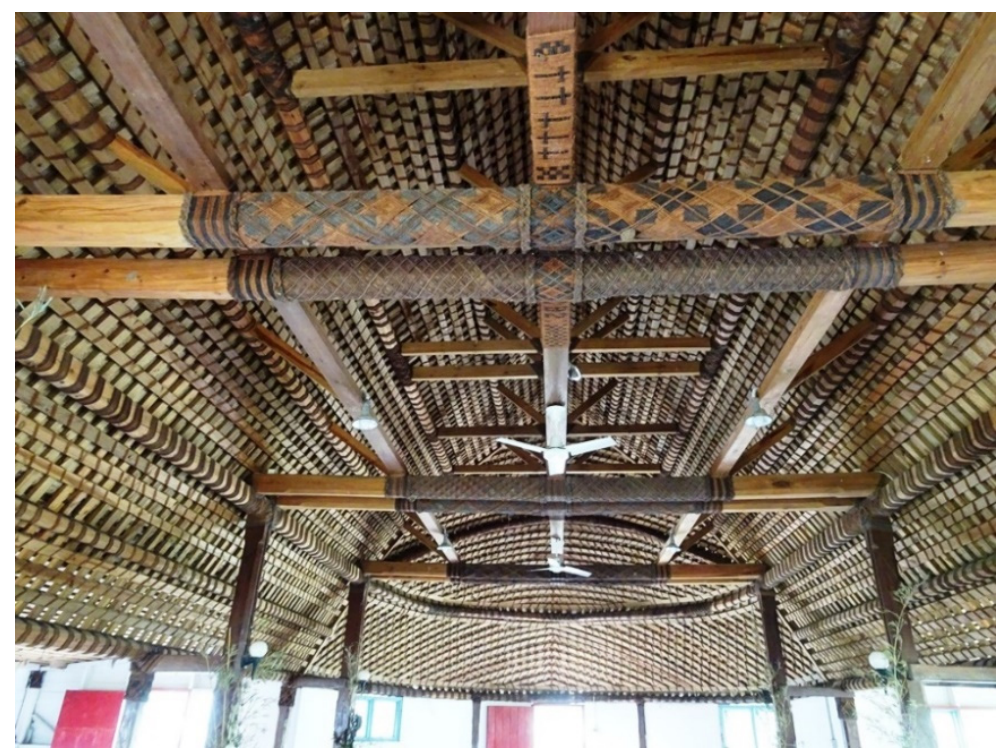

Figure 3: Roof structure of a church, Tubou village. 
With an area of 54 sq. $\mathrm{km}$ and a population (1976) of 2067 in eight villages, Lakeba is the largest of the Lau islands. Tubou is the traditional chiefly village and is the seat of the traditional paramount chief, Tui Nayau [4].

Modern accommodations are not available in Lakeba island. However, there are two homestays in this island. Arthur was invited to one of the homestays in Tubou village to look at the interior (Fig. 4(a)). Structural frameworks of the rounded roof are amazing when seen from inside. Beams and pillars under the roof are decorated with white shells. Houses are standing around Village Green (open space) where is the place being used for socialisation by villagers. Village Green is well maintained.

Cargo-passenger boats irregularly call the island once or twice a month and supply daily necessities for island life. The boats do not have fixed shipping schedule because they cannot make profits by shipping operation. Therefore, service ship and port of call are decided monthly by a bid, and the government fills a deficiency,

There is an airfield in Lakeba island. A small plane with less than 10 seats provides services between the island and Nausori airport near the capital Suva. However, air service is only once a week. If you fly to the island by a plane, you must stay the village at least seven nights. In return, you can enjoy the village life, and understand how friendly dogs are (Fig. 4(b)).

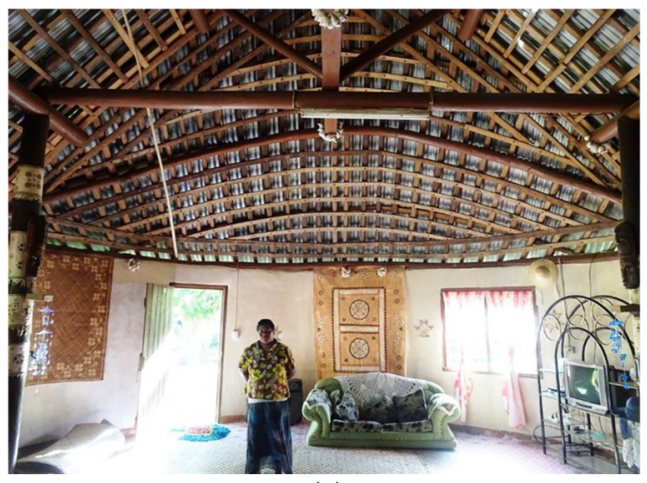

(a)

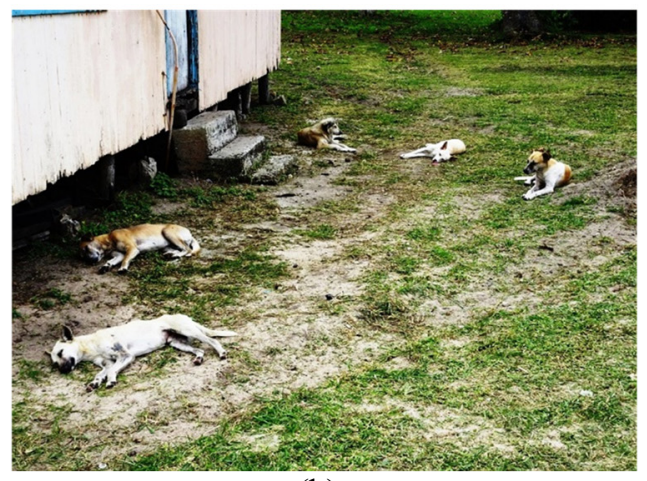

(b)

Figure 4: Tubou village, Lakeba island. (a) Inside of homestay, Lakeba island; and (b) Dogs siesta, Lakeba island.

\subsubsection{Other islands}

Matuku Is has a land area of about $28.5 \mathrm{sq}$. $\mathrm{km}$. It has seven villages and a population in 1976 of 1044 [4]. The jetty is set at geographical centre of the island [8]. A young villager said to Arthur, "A road was constructed at the back yard of the primary school in around 2000. This road was supposed to connect the center of the village with the Jetty. The road has been unused because there were no cars in the village and gradually disappeared, becoming bush, and ultimately abandoned. This island is fully protected by coral reef, and lagoon is shallow. Arthur made a sail round the Matuku Island by a small fibre boat. Water inside the lagoon was extremely crystal. The seabed covered with coral was visible even aboard the boat. Villagers in Matuku Island are living with close relationship with animals. Pigs are left free to walk around any places in the village even at school campus. They enjoy strolling with a family and are getting fat as large as a calf" (Fig. 5(a)). 


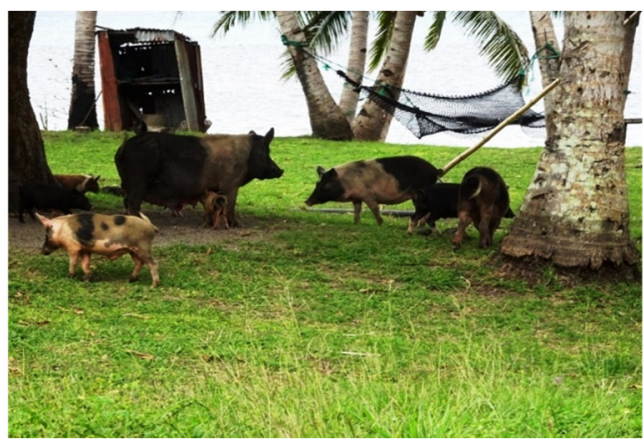

(a)

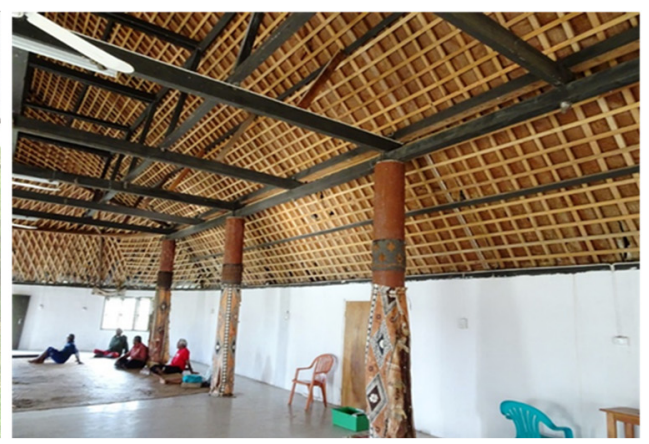

(b)

Figure 5: Island life. (a) Pig family, Matuku Island; and (b) Inside of community centre, Cicia Island.

(Vanua Balavu Is.) is the third largest island in the Lau archipelago. In 1855, Ma'af acquired sovereignty over northern Lau and established Lomaloma as the capital of the Lau Confederacy [9]. Tongan cultural influences still can be seen in the form of the architectural style in Vanua Balavu island; many houses and public buildings with rounded roof stand in Lomaloma village. Lomaloma Jetty is serviced fortnightly under the Government Shipping Franchise Scheme. Vanuabalavu Airport has a 762 m runway, and services with regular flights to/from Nausori near the capital Suva. A couple of sailing boats mooring near the mouth of Lomaloma Bay were observed from the deck of the MV Iloilovatu when she departed the Lomaloma Jetty.

(CICIA Is.) has an area of $34 \mathrm{sq}$. km with five villages. It has a population of about 1,000. There is an airfield with a runway of $762 \mathrm{~m}$. The runway is not paved but a grass field. Once a week (on Tuesday) a small aircraft connects the island with the Nausori Airport. Coastal road with gravel surface runs encircling the island. This island is serviced fortnightly under the Government Shipping Franchise Scheme. The Tongan cultural influences are still marked in the island life such as in the form of the architectural style; many houses or public buildings in the village have round shaped roof (Fig. 5(b)). Other island lifestyles may be seen during walking tour around the island. In Arthur's case an old villager was making copra fibre in the part of his garden.

\subsection{Lomaiviti archipelago}

Lomaiviti archipelago is a group of islands between Viti Levu and Lau archipelago. Ovalau, $13 \mathrm{~km}$ long and $11 \mathrm{~km}$ wide, is the principal island of this islands group. Census population of the Ovalau island is 8,360 in 2007.

\subsubsection{Ovalau island}

Levuka is the socioeconomic centre of this island (Fig. 6(b)). Moreover, Levuka was the first national capital of FIJI, and was firstly inscribed as a UNESCO world heritage site from the South Pacific islands. Unlike Lauan villages Levuka is basically European atmosphere town.

Levuka started to gain prominence in the early 1800s when European traders paid attention to sandalwood or beche-de-mer. In addition, a small whaling settlement had been built at this town by 1830 . Both Levuka's geographical location in the centre of Fiji islands 


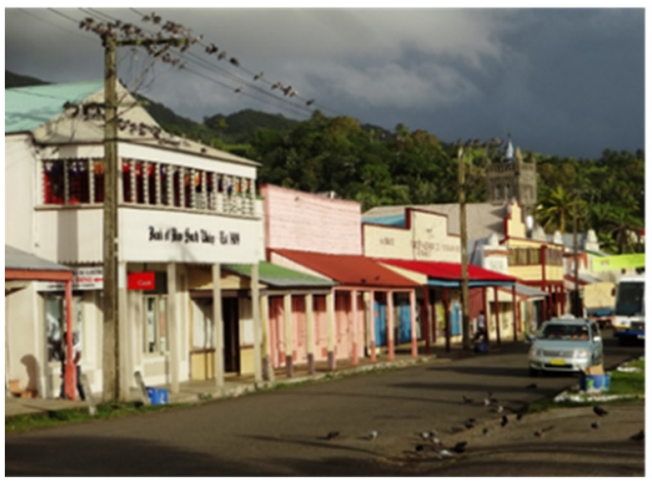

(a)

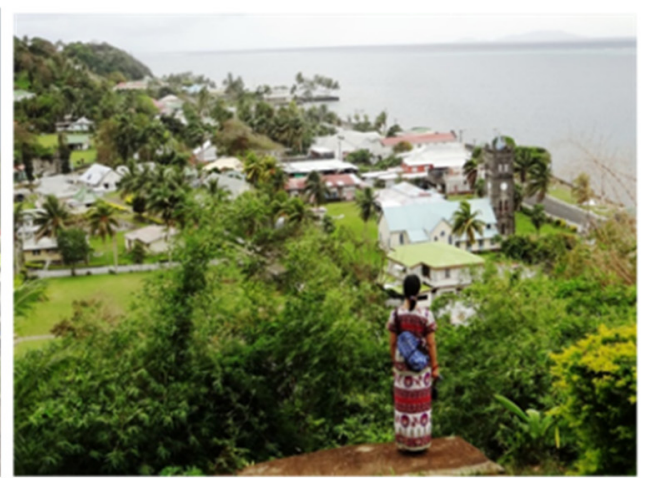

(b)

Figure 6: Levuka, Ovalau Island. (a) Colonial style architecture, Beach Street; and (b) Levuka town overlook.

and existence of sheltered harbour with two entrances/channels have contributed to establish Levuka as Fiji's commercial centre.

In 1871 Levuka became the capital of Kingdom of Fiji. After 1874 when Deed of Cession was signed, Levuka served as the Fiji's capital until 1882. Levuka has been a busy port town even after the title being the national capital was removed. Cotton trade has been booming at Levuka throughout in the 1870 s, and copra entered a trading market as a new commodity.

In June 2013 Levuka Historical Port Town was listed as UNESCO World Heritage Site (cultural) because "It is a rare example of a late colonial port town, which illustrates the cultural hybridity of non-settler communities in the Pacific, with an urban plan that merges local settlement traditions with colonial standards" [10].

Near the harbour, small scale buildings with colonial style are lined along the beach (Fig. 6(a)). Every Saturday morning people gather at an open-air market held in front of the lined shops. Lovoni people also come down with agricultural products to sell from the mountain and buy daily necessities on their return home. Within a walking distance from the port entrance, Levuka village with traditional settings lies facing a creek. Levuka is no more busy port because of limited hinterland and lack of special products except canned fish. Sometimes, however, a few sailing boats mooring at the calm basin can be seen.

\subsection{Viti Levu's adjacent islands}

\subsubsection{Bau Island}

Bau island lies about $10 \mathrm{~km}$ north of Nausori airport and is separated from the main island Viti Levu by $300 \mathrm{~m}$ long shallow waters. The highest point of the island is $15 \mathrm{~m}$ above sealevel and its land area is only eight hectares.

Despite its modest size, Bau rose to prominence in the mid-1800s and became Fiji's dominant power. Bau is the chiefly home of Bauan people, and home and stronghold of the great King Cakobau, who made his people leaders of Fiji. To come from the Bau is a status symbol for Fijian. In its heyday, the island boasted about three thousand inhabitants and it has maintained its influence in politics through to modern Fiji.

In 1852 Cakobau became Chief of Bau and Kingdom of Fiji was established by Cakobau in 1871. Deed of Cession to Great Britain was signed at Levuka in 10 October 1874. Cakobau took leadership of this deal. 
It should be noted that Ma'af, a chief and warrior from Tonga was one of the signers of this important political document. However, foreign influence and cultural exchange with them are obvious in landscape of this island.

At the field visit to Bau Island in 2017, Author was invited to the chief's residence to look inside. Usually Fijian architecture is composed of strait lines, and roofs extend upward. However, roofs of the chief's resident is circular at the ends. The chief's wife introduced herself saying, "I am related with Tonga" (Fig. 7(a)).

Village Green (open space) is situated at the central place of the island and well maintained as is the case in the Lakeba Island. The chiefly mausoleum stood on the knoll and with typical Fijian architectural style (Fig. 7(b)). Both two buildings of different architectural style stood closely with each other.

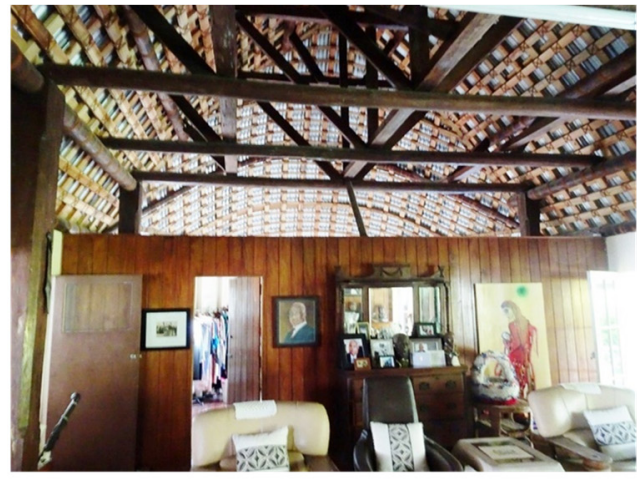

(a)

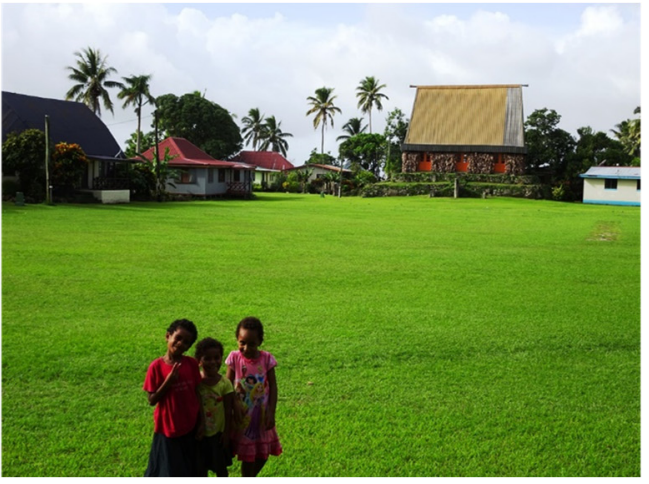

(b)

Figure 7: Various architectural styles in Bau Island. (a) Interior of the Chief's house; and (b) Fiji's traditional style architecture.

Currently the Bau Island is not completely open to tourists or visitors. Invitation is required to tourists or visitors who want to land the Bau Island because of limited land space and limited usable resources. However, tourists or visitors can enjoy village landscape and villagers lifestyle freely, encircling the island aboard fibre boats.

\subsection{Kadavu Island}

In Kadavu Island there are two jetties, Kavala Jetty and Vunisea Jetty. Through site visits it was found that they are new type of jetties from viewpoint of tourism. At $11 \mathrm{pm}$ of 31 May 2017, Lomaiviti Princess (5,864 GRT, Ro-Ro/Passenger ship) departed from Muwaiwalu Wharf, Suva where the Author embarked. The next morning, she approached the Kavala Jetty, first port of call of in the Kadavu Island. When Arthur turned back on the deck, he recognised many fibre boats coming somewhere or other toward the Ro-Ro ship. Around 9 am of 1 June 2017, she arrived at the Kavala Jetty (Fig. 8(a)).

Even before some passengers and cars have completed disembarkation there, small fibre boats came one after another to the Jetty. The boats were filled with passengers and baggage. On the backup area, tents were expanded by villagers for selling meals, oranges, talo and so on. The backup area has changed from vacant grass field to a festival marketplace.

Traditionary, jetties in Fiji do not have a backup area, but the Kavala Jetty has. Ratu Sir Kamisese Mara states as follows: 
"All candidates were invited to set out their platforms in the Fiji Times, and mine was quite simple - communications in Lau and Lomaiviti. I would work for the widening and deepening of entry passages through the reefs, small jetties with storage sheds and rudimentary feeder roads, more radio and telephone stations, a freight subsidy, and a school for boat building" [11].

At the Kavala Jetty, a spatial reclamation area has been prepared at the back yard for parking of vehicles and for an open market (Fig. 8(b)). Passengers both aboard and incoming/outgoing can take a break there and enjoy talking each other for a while. Most of the island jetties have been built solely as a ship docking point. No other functions have been taken into consideration. Progressive jetties should be planned as waterfront space, not a point, which accommodates a living function as well as a logistic function.

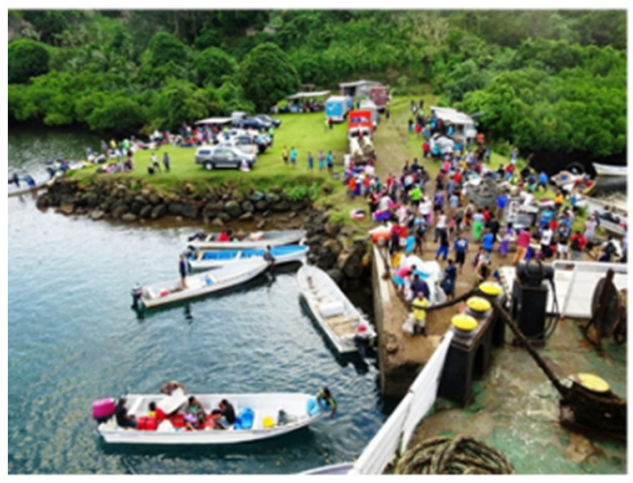

(a)

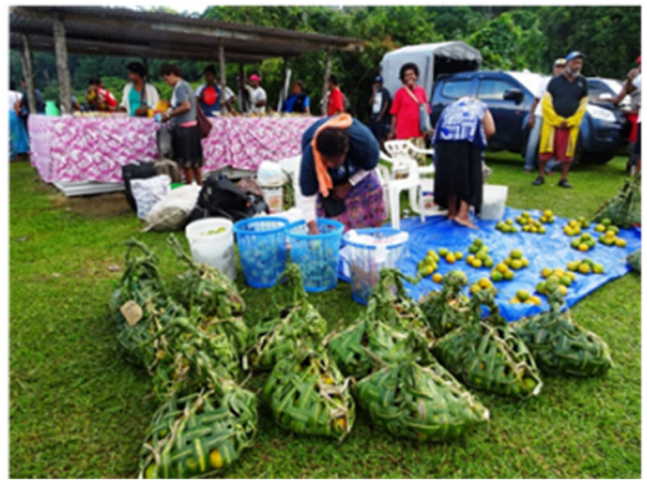

(b)

Figure 8: Island style, Kadavu Island. (a) Just after the ferry has arrived; and (b) Jetty is filled with festival atmosphere.

Kadavu is about $48 \mathrm{~km}$ in length and varies in breadth from about $365 \mathrm{~m}$ to $13 \mathrm{~km}$. Its area is $411 \mathrm{sq} . \mathrm{km}$ and an island population is about 10,000. Land transport is very limited in the Kadavu Island, and Kadavu airfield is not accessible from Kavala Village by land. Vunisea is the central place of Kadavu Island. Copra, fruits, and good timber abounds on the south and south-east slopes [4].

\subsection{Summary of field visits}

Through the field visits it was revealed that existing service level of the transportation system in Fiji remote islands was very poor and constituted one of the most serious hindrance to the development of remote island tourism. Improvement of transportation system is a must for tourism development in remote islands.

Regarding the tourist resources, each village has its own unique history and heritage. In general sense, traces of cultural influences and exchanges among different folks/races can be a potential tourist resource in remote islands in Fiji. Fig. 9 shows selected impressive scenes for the author on several remote islands. 


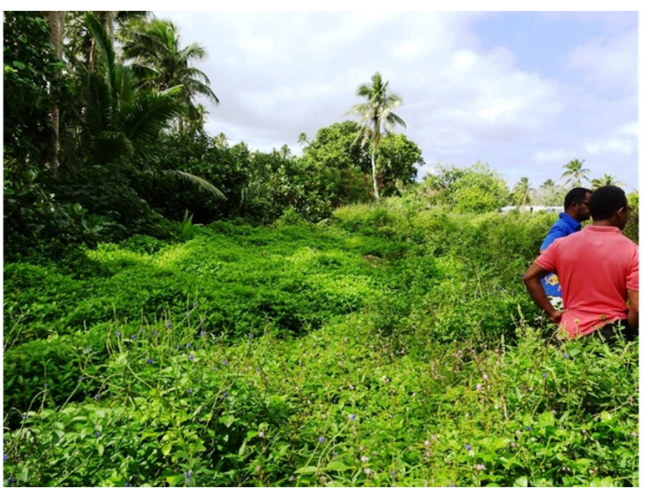

(a)

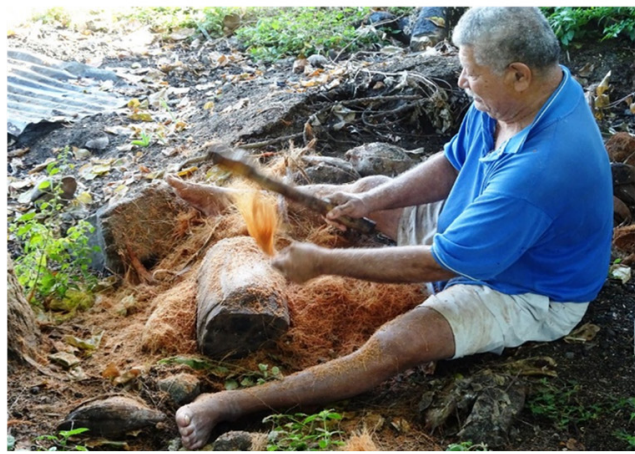

(c)

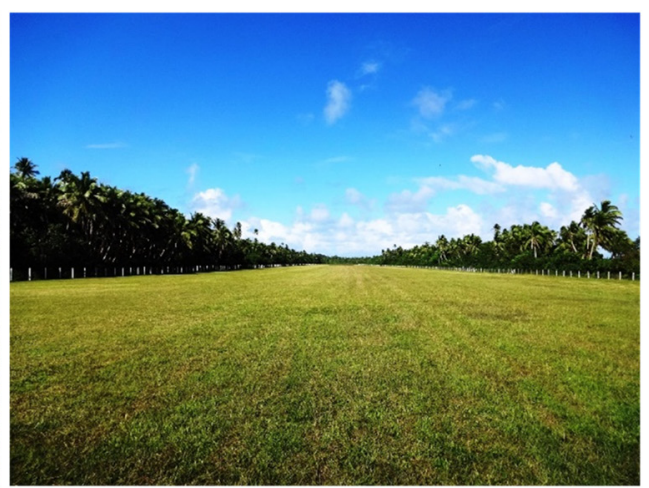

(b)

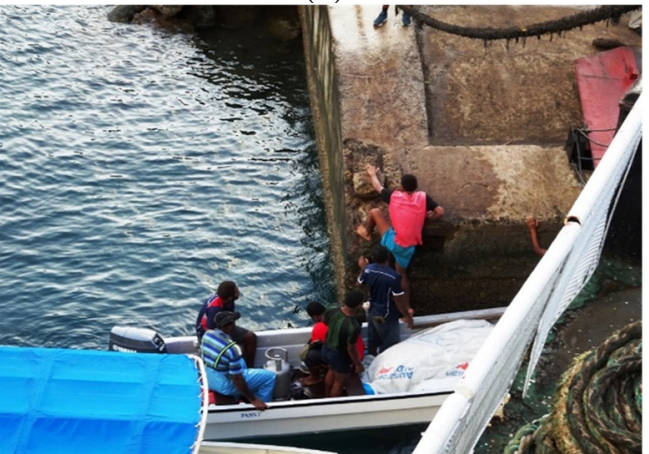

(d)

Figure 9: Selected scenes on the remote islands. (a) Disappeared tracks, Matuku Island; (b) Grass runway, Cicia airfield; (c) Copra fibre, Cicia Island; and (d) Kavala Jetty, Kadavu Island.

\section{STRATEGIES FOR INCREASING TOURISM}

Improvement of transportation infrastructure should be given the highest priority in order to materialize the remote islands tourism in Fiji. It is not an easy task to improve transportation infrastructure in a short period of time since there are about one hundred inhabited islands in Fiji's. In addition, the government budget is limited, too. Realistic ways must be adopted to materialize the goal.

"Staged development strategy" can be recommended in transportation development works to support the realization of the remote islands tourism in Fiji. It would be too optimistic to consider that upgrading the transportation infrastructure can be realised in all remote islands and number of incoming tourists would be increased simultaneously among all remote islands. Therefore, priority shall be given to a specific island group. If efficiency and effectiveness of the investment are taken into consideration, it would be reasonable to consider that the priority goes to the island group which is nearest to the national marketplace, Suva city.

The first stage of the works is to upgrade service level of the mother port in the main island. Muwaiwalu Wharf at Suva Port, which is separated from the main wharf and about $1 \mathrm{~km}$ away from the city centre, has been playing as a mother port function. However, the Muwaiwalu wharf has only $122.6 \mathrm{~m}$ in length and $48.8 \mathrm{~m}$ wide, hence the terminal is too 
small to accommodate all passengers, cargos, and vehicles of interisland shipping. In addition, it is old and deteriorated. Therefore, a new interisland terminal should be built somewhere, perhaps on the eastern coast of Viti Leve to serve for the Lau archipelago and Lomai Viti archipelago. However, the mother port function for Kadavu Island should remain at Muwaiwalu wharf in Suva Port, As Suva Port is faced to the South, most of the interisland ships must take a circuitous route when they destine to the Eastern islands. This is another reason why an additional interisland terminal should be built at a new site.

The second stage is to introduce high speed passenger boats between the new terminal and Lomai Viti archipelago to formulate one day trip sphere from Suva. Residents of Levuka say as follows.

"The introduction of fast, comfortable boats that cruise at 14 knots and accommodate 50 passengers would also boost the economy. Direct runs from Suva to Levuka on Mondays, Wednesdays, and Fridays with runs in the other direction on Tuesdays, Thursdays, and Saturdays would assist inns and restaurants. Travellers might want to visit other nearby islands, such as Cagilai, Leluvia, Lost Island, and Naigani, which would be easy with small boats" [3].

Not only island residents, but also cruise passengers want high speed passenger boats to be introduced. Cruise ships usually arrive at ports early in the morning and depart a harbour late afternoon or in the evening. Thus, cruise passengers have 7-8 hours only to make an optional tour during a stay at Port.

The third stage is to connect Lau archipelago with Lomai Viti archipelago or other islands including Taveuni island and neighbouring nations. At this stage planners are advised to make a close watch at the socioeconomic moves and changes.

\section{CONCLUSIONS}

"Blue sea and white beach" have long been placed at the centre of the destination images of Fiji. Through the field visits to Lau archipelago, Lomai Viti archipelago, and Kadavu island, it was found that "culture" is one of the important local resources of remote islands in Fiji. One of the important elements of the tourism is "a displacement outside the usual environment". "Remote island" just meets with this criterion because in modern society people tend to live in urbanised areas. Time passes slower in remote islands than in urbanised areas. Therefore, past events (history) are felt clearer for islanders than city dwellers. Unique lifestyle still exists in remote islands in Fiji. The unusual environment is felt fresh for city dwellers. Lifestyle of islanders can be one of the tourist resources for people who live in urbanised areas. it is concluded that this research made clear that "Remote island tourism" is one of the new frontiers for Fiji. Improvement of transportation infrastructure should be given the highest priority in order to materialize the remote islands tourism in Fiji. "Staged development strategy" can be recommended in transportation development works to support the realization of the remote islands tourism in Fiji.

The first stage of the works is to upgrade service level of the mother port in the main island. A new interisland terminal should be developed on the eastern coast of Viti Leve to serve for the Lau archipelago and Lomai Viti archipelago. The second stage is to introduce high speed passenger boats between the new terminal and Lomai Viti archipelago to formulate one day trip sphere from Suva. The third stage is to connect Lau archipelago with Lomai Viti archipelago or other islands including Taveuni island and neighbouring nations. At this stage planners are advised to make a close watch at the socioeconomic moves and changes. It is suggested that "Remote island tourism" should be pursued in step with developments of social basic needs. 
From discussion and consideration above, it is concluded that this research made clear that "Remote island tourism" is one of the new frontiers for South Pacific island nations.

\section{ACKNOWLEDGEMENTS}

This research work has been supported in part by Ministry of Infrastructure and Transport FIJI and Japan International Cooperation Agency (JICA). The contents of this paper are the sole responsibility of the author.

\section{REFERENCES}

[1] Kato, H., Kotu infra kara kannko wo kanngaeru-Kannko sozogaku heno Challenge, Center for Advanced Tourism Studies (CATS), Hokkaido University: Sapporo, pp. 319-325, 2017. (In Japanese.)

[2] Carter, J., Fiji Handbook: Business and Travel Guide, Pacific Publications: Sydney and New York, pp. 7-22, 1980.

[3] People of Levuka, Levuka: Living Heritage, Institute of Pacific Studies, University of the South Pacific and Levuka Historical and Cultural Society, pp. 96-97, pp. 136-137, 2001.

[4] Douglas, N. \& Douglas, N., Fiji Handbook: Business and Travel Guide, Pacific Publications: Sydney and New York, pp. 9-17, pp. 210-213, 1987.

[5] Kato, H. (ed.), Jetties and Landings in Fiji for Public Transport, Ministry of Infrastructure and Transport Fiji, Japan International Cooperation Agency (JICA): Suva, 2017.

[6] Hydrographic Office, Fiji Navy, Fiji nautical almanac 2015, Hydrographic office, Fiji Navy: Suva, Fiji, 2014.

[7] Lau Islands, Wikipedia. https://en.wikipedia.org/wiki/Lau_Islands. Accessed on: 3 Mar. 2020.

[8] Kato, H., Completion Report of H. KATO's Trip to Lau Group Island, Ministry of Infrastructure and Transport Fiji and Japan International Cooperation Agency: Suva, 2017.

[9] Lomaloma, Wikipedia. https://en.wikipedia.org/wiki/Lomaloma. Accessed on: 3 Mar. 2020.

[10] Levuka Historical Port Town, UNESCO World Heritage Centre. http://whc.unesco.org/en/list/1399/. Accessed on: 10 May 2014.

[11] Mara, K., The Pacific Way: A Memoir, University of Hawai'i Press: Honolulu, 1997. 